\title{
Cymothoid isopod parasites in aquaculture: a review and case study of a Turkish sea bass (Dicentrarchus labrax) and sea bream (Sparus auratus) farm
}

\author{
Tammy Horton, Beth Okamura* \\ The University of Reading, Whiteknights, PO Box 228, Reading RG6 6AJ, United Kingdom
}

\begin{abstract}
This paper reviews the occurrence of cymothoid isopod parasitism in aquaculture, reports the first case of infection by a cymothoid isopod (Ceratothoa oestroides) in Turkish aquaculture, and analyses its effects on sea bass Dicentrarchus labrax. Analyses revealed that $C$. oestroides negatively affects the weights and lengths of sea bass hosts. These effects have been previously underestimated because host age has not been accounted for. The analysis of condition factors as a means of assessing parasite effects is therefore likely to be misleading. Infection of fish of all ages by all cymothoid stages indicates that sea bass are not intermediate hosts but that $C$. oestroides has effected a complete host shift.
\end{abstract}

KEY WORDS: Ceratothoa $\cdot$ Parasitism $\cdot$ Aquaculture $\cdot$ Dicentrarchus labrax $\cdot$ Cymothoidae

\section{INTRODUCTION}

The culture of marine fish species in sea cages has been rapidly expanding for the past decade (Kent 2000). Important fish species in this industry include Atlantic salmon, sea bass, sea bream, turbot, and, more recently, mullet and tuna. In the Mediterranean, the production of sea bass Dicentrarchus labrax and sea bream Sparus auratus has increased rapidly in the last decade. The Mediterranean sea bass industry has expanded from producing 315 metric tons in 1984 to 17000 metric tons in 1995 (FAO 1997), and finally to producing 47000 metric tons in 2000, a $175 \%$ increase in the last 5 yr (Federation of European Aquaculture Producers, www.feap.org). Rapid increases such as these are linked with the appearance of a number of new host-parasite associations, which may result from hosts being reared in new geographic areas or from indigenous hosts being reared in different environmental conditions (Kent 2000). Parasitism of cultured

${ }^{*}$ Corresponding author. E-mail: b.okamura@reading.ac.uk sea bass and Atlantic salmon by cymothoids is one such example.

Cymothoid isopod parasites have been studied for many years, and the more recent comprehensive works have related to cymothoid taxonomy (Brusca 1981, Bruce 1986, 1987a,b, 1990, Bruce \& Bowman 1989). However, there are relatively few ecological studies and those that have been published are based on small sample sizes and/or wild fish populations (e.g., Lanzing \& O'Connor 1975, Colorni et al. 1997, Charfi-Cheikhrouha et al. 2000). As a result little is known about the life histories of the hosts. The aquaculture system provides a setting in which potential host ages are known and large sample sizes of both parasitised and unparasitised hosts are readily available. Studies of cymothoid parasites in aquaculture systems can thus complement studies of cymothoids in wild fish and provide an opportunity to obtain critical information on the effects of these parasites on their hosts.

This paper reports the first case of parasitism by a cymothoid isopod in Turkish sea bass farms and analyses the prevalences and effects of the parasites 
on sea bass hosts. As background to the study, a review of the history of cymothoid parasitism in aquaculture follows.

\section{History of cymothoid parasitism in aquaculture}

The first reports of cymothoid isopods in an aquaculture system were from sea bass Dicentrarchus labrax reared in Diana Pond in Corsica (Bragoni et al. 1983, 1984). The cymothoid Nerocila orbignyi was found infecting and killing the cultured sea bass (family Moronidae). This species is an ectoparasite that attaches to the skin and fins of fish and normally infects fish of the family Mugilidae. Bragoni et al. (1983) reported a decrease in condition factor and a decrease in weight of parasitised compared with unparasitised fish. Bragoni et al. (1984) reported on the ecology of the host parasite relationship and noted periods of sea bass mortalities, some of which were attributable to $N$. orbignyi. Parasite prevalences reached $90 \%$ in wild mullets (Mugilidae) in August and these were considered the most likely source of the sea bass infection, due to their habit of feeding around the sea cages (Bragoni et al. 1984). Subsequent reports of cymothoids in aquaculture include Ceratothoa gaudichaudii in salmon Salmo salar farms in Chile (Alvarado et al. 1990, Roa 1992, Inostroza et al. 1993, Sievers et al. 1996), Emetha audouini infecting sea bass farms in Greece (Papapanagiotou et al. 1999), and Ceratothoa oestroides in sea bass farms in Croatia Šarušic 1999).

In Chilean salmon farms, studies were carried out to determine the effect of the parasite Ceratothoa gaudichaudii on the host fish. Significantly reduced weights were recorded in similarly aged hosts with more than 8 parasites compared with those harbouring 3 to 8 parasites and fewer than 3 parasites. The parasites have not been reported on wild or cultured Salmo salar in the northern hemisphere and in Chile are normally found infecting Trachurus murphyi, a fish that schools around the sea cages in the summer months (Sievers et al. 1996).

In 1999, Papapanagiotou et al. (1999) reported Emetha audouini juveniles infecting and causing a cumulative mortality of $10.75 \%$ in $30 \mathrm{~g}$ sea bass. This parasite has never been reported infecting sea bass in the wild and is normally found infecting fish of the families Sparidae and Centracanthidae (Papapanagiotou et al. 1999).

An infection by Ceratothoa oestroides of sea bass and sea bream was recorded at a farm in Croatia Šarušic 1999). Šarušic states that the parasite could be found at any time of year in market sized sea bass but apparently not in market sized sea bream Sparus aura- tus. However, the juveniles infected fry of both fish species. The wild fish feeding around the cages were viewed to be the likely source of the infection, and wild bogue Boops boops were reported as carrying the parasite (Šarušic 1999). Mortalities of 10 to $20 \%$ were reported in both bass and bream fingerlings up to $10 \mathrm{~g}$, and a $20 \%$ reduction in growth rate was noted in the adult fish (Šarušic 1999).

Papoutsoglou et al. (1996) noted a single occurrence of a cymothoid isopod on a sea bass in 1991 at a fish farm in Greece. Although the appearance of a single isopod does not constitute a problem it is worth mentioning here.

None of these cymothoid species that have been reported in fish farms are known to parasitise wild sea bass, sea bream, or salmon and all are suspected to have been transferred to cultured fish from wild fish (Bragoni et al. 1983, Sievers et al. 1996, Šarušic 1999, Papapanagiotou et al. 1999).

\section{Case study of cymothoid parasites in a Turkish sea bass farm}

In 1999 cymothoid parasites were first observed in a sea bass fish farm in Turkey (T. Meyer pers. comm.). Their continued presence prompted the current investigation to determine the species causing the infections and to investigate the prevalence and effects of the cymothoid on sea bass hosts.

\section{MATERIALS AND METHODS}

The study was carried out at a sea bass Dicentrarchus labrax and sea bream Sparus auratus farm (Pınar Deniz Ürünleri) situated in the Aegean Sea near Çeşme. The farm has been on the site for $15 \mathrm{yr}$ and is one of the oldest fish farms in Turkey.

Prevalences were determined in both July and September 2000 by sampling approximately 50 fish from each sea cage studied. In September the total length (in millimetres) and the weight (in grams) of each of the 50 fish per cage were measured. These data were used to analyse the effects of cymothoid parasitism on fish weights, lengths and condition factors. The latter have been used extensively as a means of assessing the health of fish and are calculated as follows:

$$
K=\left(W / L^{3}\right) 100
$$

where $K$ is condition factor, $W$ is weight in grams and $L$ is length in centimetres.

Parasites were removed from all parasitised fish and placed in a labelled tube for later study. The number of parasites and their life stages were recorded. 
Statistical analysis. The effects of cymothoid parasitism on fish growth were analysed in several ways. First we conducted a non-linear regression analysis on parasitised and unparasitised fish of known age. This approach identifies the best regression model for the data and allows comparison of such models for different parasite loads. In particular we compared regressions of lengths with age for fish carrying 0,1 , and 2 or more parasites. We did not assess effects of manca larvae since they moult to juveniles within a few days of infecting fish hosts (Horton pers. obs.), a time period we deemed to be insufficient to greatly influence growth. Juveniles and adult males and females were not distinguished in the analyses. Our aim was to identify the total effect of parasitism on fish growth, rather than the effects of different life history stages. Identification of these effects would potentially be obscured by the sample sizes available and variation in host age within these samples.

We also conducted a nested ANOVA in order to assess the effects of parasite load, age of fish, and cage on fish lengths. This analysis allowed us to determine whether parasite load alone influences growth. In addition, as an illustrative example, we assessed the effects of parasitism on fish growth by 1-way ANOVA, by comparing the lengths and weights of parasitised and unparasitised fish of a known age. We chose the age group with the largest sample size for this analysis. Note that this involved pooling fish of the same age that were present in several cages. This approach provides specific illustration of the results of the non-linear regression modelling and nested ANOVA. The KolgomorovSmirnoff test for normality, and Bartlett's and Levene's tests for equality of variance were used before ANOVA.

Finally we assessed the relationships between fish age, fish length, exposure time, and prevalence (for the September samples) using Spearman rank-order correlations. Condition factors were compared using a Mann-Whitney $U$-test. Analyses were conducted using Minitab (release 13.1) and SAS (version 8.00).

\section{RESULTS}

\section{Parasite species identification and analyses of prevalence}

The main parasite species infecting sea bass at the site was identified as Ceratothoa oestroides (Trilles 1972, Horton 2000). Nerocila orbignyi was also found on 1 sea bass. C. oestroides infected sea bass of all ages (range of fish age 176 to $612 \mathrm{~d}$ ) on the farm and all stages of development of the parasite were pre-
Table 1. Prevalences (percentage of fish infected) for the 8 cages that were sampled in both July and September 2000. $\mathrm{n}$ : number of fish sampled

\begin{tabular}{|cc|}
\hline Prevalence in July (n) & Prevalence in September (n) \\
\hline $55(50)$ & $53(42)$ \\
$36(50)$ & $45(38)$ \\
$27(50)$ & $32(50)$ \\
$59(50)$ & $64(50)$ \\
$54(43)$ & $36(50)$ \\
$32(50)$ & $45(42)$ \\
$36(46)$ & $24(48)$ \\
$64(42)$ & $66(50)$ \\
\hline
\end{tabular}

sent (juveniles, males, non-ovigerous, and ovigerous females). This confirms that the parasite is not simply using the sea bass as an intermediate host but that a complete host shift has occurred. Infection levels of C. oestroides at the time of study were extensive. The prevalences ranged from 1 to $68 \%$ (mean \pm SD $23.11 \pm 16.71)$ in the 109 cages that were sampled in July and from 0 to $66 \%(13.51 \pm 17.51)$ in the 53 cages sampled in September. Table 1 shows prevalences of cages containing the same fish stock that were sampled in both July and September. After arcsine transformation of the data, a paired $t$-test showed that there was no difference between the 2 sets of data $(t=-0.51, \mathrm{df}=7, \mathrm{p}=0.624)$, indicating that over this 2 mo period prevalences remained the same.

Spearman rank-order correlations indicated (1) a very weak positive correlation between prevalence and age $\left(\mathrm{r}_{\mathrm{s}}=0.391, \mathrm{df}=51, \mathrm{p}<0.05\right)$ (Fig. 1); (2) a very weak positive correlation between host mean length and prevalence $\left(\mathrm{r}_{\mathrm{s}}=0.316, \mathrm{df}=48, \mathrm{p}<0.05\right)$ (Fig. 2); and (3) a very weak positive correlation between host exposure time (time in days in sea cages) and prevalence $\left(\mathrm{r}_{\mathrm{s}}=0.367, \mathrm{df}=52, \mathrm{p}<0.05\right)$ (Fig. 3).

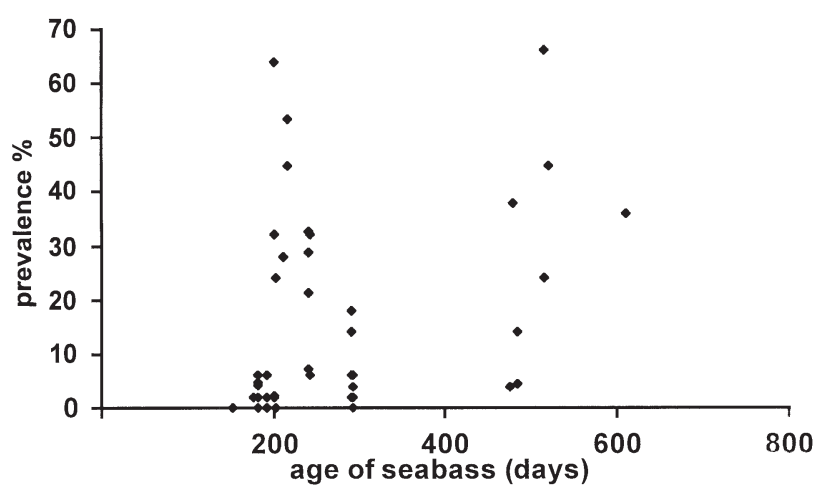

Fig. 1. Prevalence (percentage of infected hosts) against age in days of sea bass hosts 


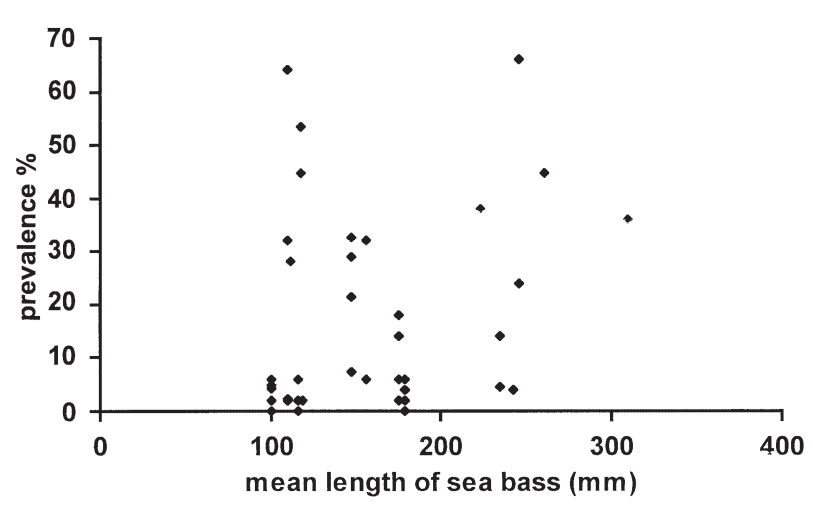

Fig. 2. Prevalence (percentage of infected hosts) against mean length in millimetres of sea bass hosts

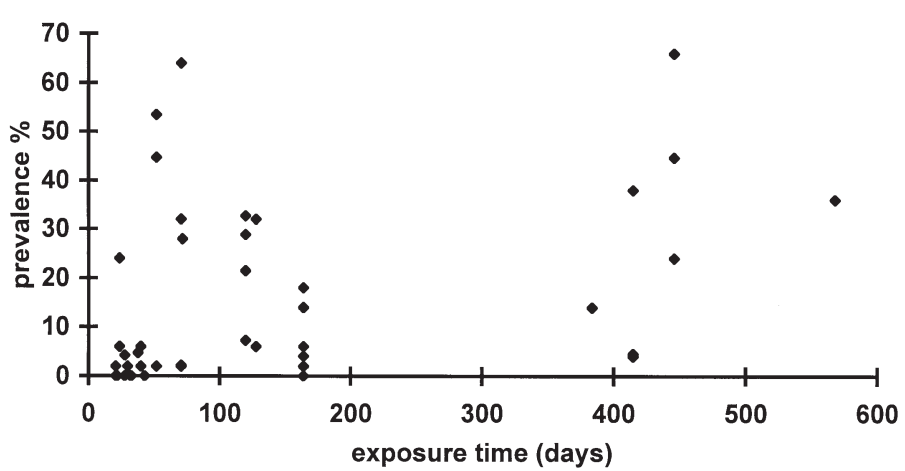

Fig. 3. Prevalence (percentage of infected hosts) against exposure time in days of sea bass hosts

\section{Non-linear regression models}

The growth curves obtained by non-linear regression of the log-lengths of fish versus fish age are shown in Fig. 4. A suitable model to represent these relationships between length and age takes the form

$$
\log _{\mathrm{e}}(\text { length })=a+b \mathrm{e}^{-c(x-150)}
$$

where $x$ is age in days and $a, b$, and $c$ are parameters of the model. Fig. 4 shows that the fits associated with different parasite loads $(0,1$, and $2+)$ differ both

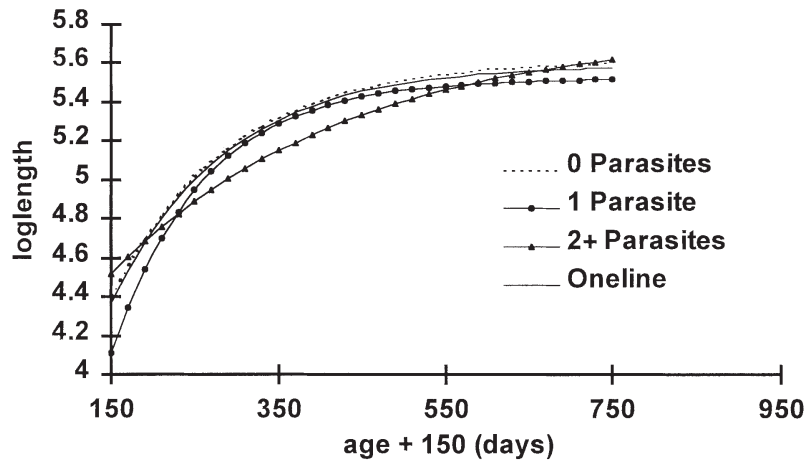

Fig. 4. Non-linear regressions of loglength versus age for parasite loads 0,1 , and $2+$ and a fit of all the data plotted together (oneline)

from each other and from a fit of all the data plotted together (oneline). The difference between individual fits and a fit of all the data is highly significant at the $p=0.001$ level (Table 2). This shows that the parasite load has a significant effect on length of the host. The most pronounced effect is seen in fish with 2 or more parasites $(2+)$, where the growth is effectively slower.

\section{ANOVA on parasitism and fish growth}

A nested ANOVA (Table 3) revealed a significant effect of the factors parasite load, age, and cage(age) on length of fish hosts. The inclusion of the cage(age) effect enables the use of the cage(age) mean square value as an estimate of the random error between cages when comparing parasite load and age. This is because the experimental unit in this study is the cage and not the individual fish. A new $F$ value was calculated using the cage adjusted means square value as the residual (i.e., $F=$ parasite load adjusted mean squares divided by cage(age) adjusted mean squares). Parasite load still has a significant effect on length of the host fish when the cage effect is included $\left(F_{3,15}=\right.$ 5.61, p $<0.01)$.

ANOVA revealed that parasitised fish (291 to $293 \mathrm{~d}$ old) were significantly lighter (by $20.1 \%)\left(F_{1,647}=\right.$

Table 2. ANOVA table showing significance of the difference between individually fitted regressions for 0,1 , and $2+$ parasites per fish and of all data plotted together (oneline). ${ }^{* *} \mathrm{p}<0.0001$. DMS: difference mean squares value; RMS: root mean square

\begin{tabular}{|c|c|c|c|c|c|}
\hline Source & df & SS & $\mathrm{MS}=\mathrm{SS} / \mathrm{df}$ & $F=\mathrm{DMS} / \mathrm{RMS}$ & $\begin{array}{c}F \text { crit. at } \\
\mathrm{p}=0.0001\end{array}$ \\
\hline Difference (b) - (a) & 6 & 2.44 & 0.406 & $37.36^{* *}$ & 3.76 \\
\hline Residual from fit of individual parasite loads (b) & 1809 & 19.66 & 0.011 & & \\
\hline Residual from fit of all data (a) & 1815 & 22.09 & & & \\
\hline
\end{tabular}


Table 3. Table of results for the nested ANOVA of length of fish hosts with the factors parasite load, age, and cage(age). ${ }^{* *} p<0.0001$. Seq SS: sequential sum of squares; Adj MS/SS: adjusted sum of squares/mean squares

\begin{tabular}{|lrrrrr|}
\hline Source & \multicolumn{1}{c}{ df } & \multicolumn{1}{c}{ Seq SS } & Adj SS & Adj MS & $F$ \\
\hline Parasite load & 3 & 1.55997 & 0.21638 & 0.07213 & 56.31 \\
Age & 15 & 26.32797 & 26.16339 & 1.74423 & 1361.71 \\
Cage(age) & 21 & 0.27013 & 0.27013 & 0.01286 & 10.04 \\
Residual & 1789 & 2.29154 & 2.29154 & 0.00128 & $0.000^{* *}$ \\
Total & 1828 & 30.44960 & & & \\
\hline
\end{tabular}

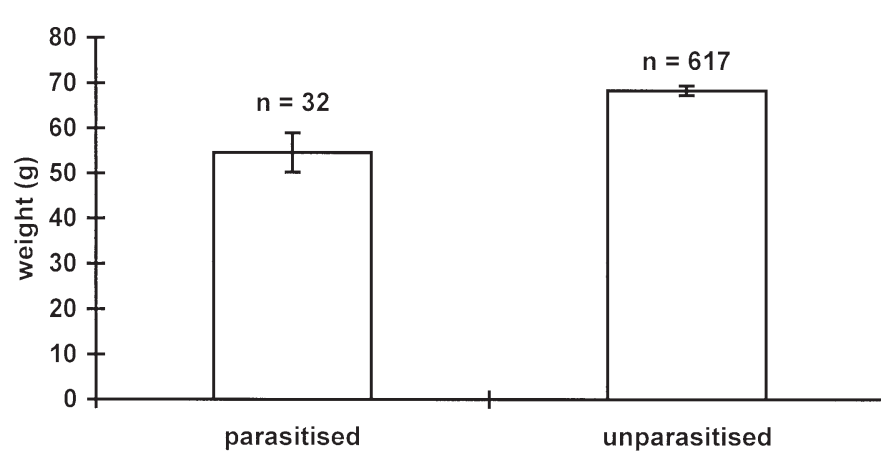

Fig. 5. Mean weights $( \pm 95 \%$ confidence intervals) for parasitised and unparasitised sea bass hosts of the same age

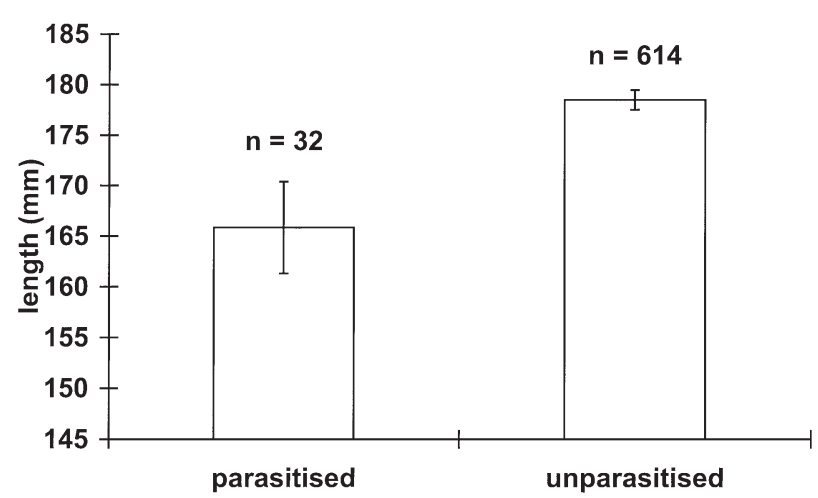

Fig. 6. Mean lengths $( \pm 95 \%$ confidence intervals $)$ for parasitised and unparasitised sea bass hosts of the same age

32.49, p < 0.001) (Fig. 5) and significantly shorter (by $7.1 \%)\left(F_{1,645}=30.79, \mathrm{p}<0.001\right)($ Fig. 6) than unparasitised fish.

\section{Analysis of condition factors}

A Mann-Whitney $U$-test indicated that the condition factors of parasitised fish were significantly higher than those of unparasitised fish ( $W=1072041$, p < 0.0001), suggesting they were heavier for their lengths than unparasitised fish.

\section{DISCUSSION}

\section{Cymothoids in Turkey}

This report of an infection of cultured sea bass with cymothoids is the first such record for Turkey. Both Ceratothoa oestroides and Nerocila orbignyi were found infecting the sea bass although only $C$. oestroides was causing a significant problem at the farm. Both of these species have been recorded infecting cultured sea bass in previous studies in different countries in the Mediterranean (Bragoni et al. 1983, 1984, Šarušic 1999).

\section{Prevalence of cymothoids and effects on sea bass}

There was a wide range of prevalence within the farm, with the highest prevalence being 66\%. Prevalences in previous reports from other farms have been recorded to reach $100 \%$ in some cases (Bragoni et al. 1983, 1984, Inostroza et al. 1993, Sievers et al. 1996). These high values occurred in the warmer months of the year. While the prevalences at the farm in this study may vary throughout the year, as has been seen in other studies (Bragoni et al. 1983, 1984, Inostroza et al. 1993, Sievers et al. 1996), there was no significant difference in prevalence between cages that were sampled in July and and those sampled in September. However, since these time periods are both during warmer months of the year, it is possible that prevalences vary seasonally.

The prevalences varied dramatically between cages of fish of similar ages. There appeared to be little relationship between prevalence and age of the hosts, mean lengths of hosts, or time of exposure to the infectious free-swimming juveniles. The differing prevalences could be due to genetic differences in the fish hosts themselves since not all fish come from the same broodstock source and it is possible that some fish have a genetic predisposition to infection and poor growth. The presence of other diseases within certain cages may also enhance susceptibility to infection by Ceratothoa oestroides. However, all fish appeared other- 
wise healthy and there was no evidence of other diseases (T. Meyer pers. comm.). No further studies of other parasites and diseases were possible since the fish could not be killed. Alternatively the variation in prevalences between cages could be due to the positioning of the cages with respect to the prevailing current from offshore (where larger fish are caged) to onshore (where smaller fish are kept). This current could act as a source of free swimming infective juveniles from the older fish, which carry most of the ovigerous females (Horton unpubl.), to the smaller fish in those cages most exposed to the current.

The separation of older from younger fish is crucial in preventing reinfection within a fish farm due to the potential supply of infective juveniles in currents. This should be incorporated in any management strategy to control this disease. However, older farmed fish may not be the only source of the free-swimming juveniles. Ceratothoa oestroides has not been found infecting sea bass in the wild, and the disease on fish farms thus appears to be the result of a host shift reflecting the broad host specificity of the species. Since many feral fish congregate around aquaculture cages to feed on leftover food pellets, the infection is likely to have originated from release of larvae by passing fish. In particular the bogue Boops boops is commonly seen around and even inside the sea cages on the Turkish fish farm (Horton pers. obs.) and is one of the known hosts of $C$. oestroides (Trilles 1994, Horton 2000). Šarušic (1999) found $C$. oestroides infecting feral bogue around sea bass cages infected with the parasite.

\section{Effects of Ceratothoa oestroides on Dicentrarchus labrax}

The pathogenic effect caused by the presence of cymothoid parasites appears, from results of both this study and those of others, to be more pronounced in those fish harbouring most parasites. This study found that the growth of fish harbouring 2 or more parasites is significantly slower than the growth of fish with 1 or no parasites in the buccal cavity. For the age group 291 to $293 \mathrm{~d}$, we found a $14 \mathrm{~g}(20.1 \%)$ difference in the mean weights, and a $12.63 \mathrm{~mm}(7.1 \%)$ difference in the mean lengths of parasitised and unparasitised sea bass. Other authors have reported similar effects. Sievers et al. (1996) observed a 15\% reduction in mean body weight in salmon hosts with $>8$ parasites, relative to that of salmon hosts with 0 to 2 parasites. A reduction in growth by $20 \%$ was reported by Šarušic (1999), although there is no reference as to how this reduction was measured.

Condition factors and length-weight relationships have been used by various authors to quantify an effect of parasites on hosts. However, as cautioned by Williams \& Bunkley-Williams (2000) and as illustrated by our results, condition factors are not a very sensitive measure of pathology caused by cymothoid parasites, and can even produce spurious results. Although we found a statistically significant difference in condition factors of parasitised and unparasitised fish, this difference suggested that the parasitised fish were heavier at a certain length than were the unparasitised hosts. Yet when age is taken into account it is clear that the parasitised fish are lighter than the unparasitised fish. Other studies of condition factors of fish with cymothoid infections have found the reverse (Bragoni et al. 1983, Lanzing \& O'Connor 1975), while yet others have found no significant difference between condition factors of parasitised and unparasitised fish (Colorni et al. 1997, Romestand \& Trilles 1979, Williams \& BunkleyWilliams 2000). This range of results further supports the unsuitability of condition factor analysis (Williams \& Bunkley-Williams 2000) and confirms that inclusion of age is necessary to illustrate proportional stunting caused by isopod infection. Working with hosts of known ages (as is the case with cultured fish) overcomes this problem.

In addition to inhibition of growth, cymothoid induced mortalities have been reported on occasion. Mortalities have been recorded in younger fish in previous reports (Šarušic 1999, Bragoni et al. 1984, Papapanagiotou et al. 1999, Williams \& Bunkley-Williams 2000) and have been noted on the farm in this study ( $T$. Meyer pers. comm.). These mortalities often occur at a low level and are caused by the large numbers of infective juveniles that attach to small fish and feed voraciously before finding a final host (Bragoni et al. 1984, Bunkley-Williams \& Williams 1998, Šarušic 1999, Papapanagiotou et al. 1999, Williams \& BunkleyWilliams 1994, 1996, 2000). This feeding can result in damage to or loss of the gill filaments, which can in turn lead to respiratory failure and death (Šarušic 1999).

\section{Control of cymothoids}

It is now clear that cymothoid isopods are causing a significant problem in aquaculture in both the Mediterranean Sea and Chile. The economic loss associated with reduced fish growth and mortality has yet to be quantified. Management strategies to control cymothoid infections have received little attention although some reports have mentioned control methods. To control an infection, simple management practices were applied to regulate infection of sea bass by juvenile cymothoids (Bragoni et al. 1984, Papapanagiotou et al. 1999). These included removal of dead and moribund 
fish, use of a fine meshed net, changing fouled nets, and moving the affected cages to open sea where stronger currents, lower temperatures, and greater depths are found. Sievers et al. (1995) evaluated the efficacy and toxicity of 8 insecticides for use in controlling Ceratothoa gaudichaudii on Salmo salar in Chile. They concluded that trichlorfon (300 ppm) and dichlorvos (3 ppm) were effective in removing $100 \%$ of parasites after 60 min exposures without toxicity to the fish hosts. Athanassopoulou et al. (2001), in a study of deltamethrin treatments, concluded that $0.05 \mathrm{mg} \mathrm{l}^{-1}$ was sufficient to kill $C$. oestroides in sea bass within $2 \mathrm{~h}$. However, as was noted by Papapanagiotou et al. (1999), care should be taken in using such guidelines in the warmer waters of the Mediterranean, since no toxicity studies have been performed for the use of such chemicals on sea bass and sea bream. In addition, it is always advisable to assess the effects of chemicals on the local biota.

\section{CONCLUSION}

By studying very large numbers of infected and uninfected sea bass of known ages, we have provided the first strong evidence that cymothoid infections reduce the growth of fish hosts in an aquaculture system. Our results also clearly illustrate the importance of incorporating the age of fish hosts in any assessment of parasite effects. Thus, caution should be applied in interpretation of condition factor analysis. Since sea cages are stocked with fish of known ages they provide a convenient means of sampling large numbers of fish hosts in order to study the effects of parasites. However, we recognise that stocking fish at high densities may lead to stress that could both increase susceptibility to cymothoid infections and lead to an inhibition of host growth. It is unclear whether cymothoids produce similar effects on wild fish populations. Further study of the effects of these parasites in both farmed and wild fish populations is therefore required to understand the biology of cymothoid parasites and their effects.

Acknowledgements. This work is supported by the University of Reading. We would particularly like to thank Trevor Meyer and the staff at Pınar Deniz Ürünleri for enabling the work in Turkey to run smoothly, and Derek Pike of the Applied Statistics Department (University of Reading) for advice and help with statistical analysis.

\section{LITERATURE CITED}

Alvarado V, Schäfer JW, Enriquez R, Monras M (1990) Salmonicultura en Chile, estado actual, proyecciones y estado sanitario. Medio Ambiente 11:9-14

Athanassopoulou F, Bouboulis D, Martinsen B (2001) In vitro treatments of deltamethrin against the isopod parasite Ceratothoa oestroides, a pathogen of sea bass Dicentrarchus labrax L. Bull Eur Assoc Fish Pathol 21:26-29

Bragoni G, Romestand B, Trilles JP (1983) Parasitoses a cymothoadien chez le loup (Dicentrarchus labrax Linneaus, 1758) en élevage II. Écophysiologie parasitaire dans le cas de l'étang de Diana (Haute-Corse). Ann Parasitol Hum Comp 58:593-609

Bragoni G, Romestand B, Trilles JP (1984) Parasitoses a cymothoadien chez le loup Dicentrarchus labrax (Linneaus, 1758) en élevage I. Écologie parasitaire dans le cas de l'ètang de Diana (Haute-Corse) (Isopoda Cymothoidae). Crustaceana 47:44-51

Bruce NL (1986) Australian Pleopodias Richardson, 1910, and Anilocra Leach, 1818 (Isopoda: Cymothoidae), Crustacean parasites of marine fishes. Rec Aust Mus 39:85-130

Bruce NL (1987a) Australian Renocila Miers, 1880 (Isopoda: Cymothoidae), crustacean parasites of marine fishes. Rec Aust Mus 39:169-182

Bruce NL (1987b) Australian species of Nerocila Leach, 1818, and Creniola n. gen. (Isopoda: Cymothoidae), crustacean parasites of marine fishes. Rec Aust Mus 39:355-412

Bruce NL (1990) The genera Catoessa, Elthusa, Enispa, Ichthyoxenus, Idusa, Livoneca, and Norileca n. gen. (Isopoda: Cymothoidae), crustacean parasites of marine fishes, with descriptions of eastern Australian species. Rec Aust Mus 42:247-300

Bruce NL, Bowman TE (1989) Species of the parasitic isopod genera Ceratothoa and Glossobius (Crustacea: Cymothoidae) from the mouths of flying fishes and halfbeaks (Beloniformes). Smithson Contrib Zool 489:1-28

Brusca RC (1981) A monograph on the Isopoda Cymothoidae (Crustacea) of the eastern Pacific. Zool J Linn Soc 73: 117-199

Bunkley-Williams L, Williams EH Jr (1998) Isopods associated with fishes: a synopsis and corrections. J Parasitol 84: 893-896

Charfi-Cheikhrouha F, Zghidi W, Ould Yarba L, Trilles JP (2000) Les Cymothoidae (Isopodes parasites de poissons) des côtes tunisiennes: écologie et indices parasitologiques. Syst Parasitol 46:143-150

Colorni A, Trilles JP, Golani D (1997) Livoneca sp. (Flabellifera: Cymothoidae), an isopod parasite in the oral and branchial cavities of the Red Sea silverside Atherinomorus lacunosus (Perciformes, Atherinidae). Dis Aquat Org 31: $65-71$

FAO Inland Water Resources and Aquaculture Service, Fishery Resources Division (1997) Review of the state of world aquaculture. FAO Fisheries Circular, No 886, Rev.1. Rome, FAO

Horton T (2000) Ceratothoa steindachneri (Isopoda: Cymothoidae) new to British waters with a key to north-east Atlantic and Mediterranean Ceratothoa. J Mar Biol Assoc UK 80:1041-1052

Inostroza R, Sievers G, Roa J, Aguirrebeña R (1993) Prevalencia e intensidad de infección estacional por Ceratothoa gaudichaudii en salmones Salmo salar cultivados en agua de mar en el sur de Chile. Arch Med Vet 25:173-179

Kent ML (2000) Marine netpen farming leads to infections with some unusual parasites. Int J Parasitol 30:321-326

Lanzing WJR, O'Connor PF (1975) Infestations of luderick (Girella tricuspidata) populations with parasitic isopods. Aust J Mar Freshw Res 26:355-361

Papapanagiotou EP, Trilles JP, Photis G (1999) First record of Emetha audouini a cymothoid isopod parasite from cultured sea bass Dicentrarchus labrax in Greece. Dis Aquat Org 38:235-237 
Papoutsoglou S, Costello MJ, Stamou E, Tziha G (1996) Environmental conditions at sea cages, and ectoparasites on farmed European sea bass Dicentrarchus labrax and gilthead sea bream Sparus aurata at two farms in Greece. Aquacult Res 27:25-34

Roa J (1992) Contribución al estudio del isópodo Ceratothoa gaudichaudii como parásito de salmones (Salmo salar) cultivados en agua de mar en dos centros de cultivo de la Provincia de Llanquihue. Thesis, M.V. Universidad Austral de Chile, Escuela de Medicina Veterinaria, Valdivia

Romestand B, Trilles JP (1979) Influence des Cymothoadiens Meinertia parallela et Anilocra physodes (Crustacés, Isopodes; parasites de poissons) sur la croissance des poissons hôtes Boops boops et Pagellus erythrinus (Sparidés). Z Parasitenkd 59:195-202

Šarušic G (1999) Preliminary report of infestation by isopod Ceratothoa oestroides (Risso, 1826) in marine cultured fish. Bull Eur Assoc Fish Pathol 19:110-112

Sievers G, Palacios P, Inostroza R, Dölz H (1995) Evaluation of the toxicity of 8 insecticides in Salmo salar and the in vitro effects against the isopode parasite Ceratothoa. Aquaculture 134:9-16

Editorial responsibility: Wolfgang Körting,

Hannover, Germany
Sievers G, Lobos C, Inostroza R, Ernst S (1996) The effect of the isopod parasite Ceratothoa gaudichaudii on the body weight of farmed Salmo salar in southern Chile. Aquaculture 143:1-6

Trilles JP (1972) Les Cymothoidae (Isopoda, Flabellifera) des côtes françaises (systématique, faunistique, écologie et répartition géographique). I: Les Ceratothoinae Schiœdte et Meinert, 1883. Bull Mus Natl Hist Nat Paris 3ème Sér 91(zool 70):1191-1230

Trilles JP (1994) Les Cymothoidae (Crustacea, Isopoda) du monde (Prodrome pour une faune). Stud Mar 21/22:1-288

Williams EH Jr, Bunkley-Williams L (1994) Four cases of unusual crustacean-fish associations and comments on parasitic processes. J Aquat Anim Health 6:202-208

Williams EH Jr, Bunkley-Williams L (1996) Parasites off shore, big game sport fishes of Puerto Rico and the Western North Atlantic. Puerto Rico Department of Natural and Environmental Resources, San Juan, and Department of Biology, University of Puerto Rico, Mayagüez

Williams EH Jr, Bunkley-Williams L (2000) On the generic placement of 'Livoneca sp.' a critique of Colorni et al. (1997). Dis Aquat Org 40:233-234

Submitted: March 25, 2001; Accepted: August 6, 2001 Proofs received from author(s): September 25, 2001 